\title{
First Record of Paramphistomes Fischoederius cobboldi and Paramphistomum epiclitum Detected in Bovine Rumen from a Local Market of Savannakhet Province, Lao PDR
}

\author{
Surapol Sanguankiat ${ }^{1}$, Marcello Otake Sato ${ }^{2,3, *}$, Megumi Sato ${ }^{4}$, Wanna Maipanich ${ }^{1}$, Tippayarat Yoonuan', \\ Tiengkham Pongvongsa ${ }^{5}$, Boungnong Boupha ${ }^{6}$, Yuichi Chigusa ${ }^{2}$, Kazuhiko Moji ${ }^{7}$, Jitra Waikagul' \\ ${ }^{1}$ Department of Helminthology, Faculty of Tropical Medicine, Mahidol University, Bangkok, Thailand; '2Department of Tropical Medicine and \\ Parasitology, Dokkyo Medical University, Tochigi, Japan; ${ }^{3}$ Curso de Medicina, Universidade Federal do Tocantins, Palmas, Tocantins, Brasil; \\ ${ }^{4}$ Graduate School of Health Sciences, Niigata University, Niigata, Japan; ${ }^{5}$ Station of Malariology, Parasitology, and Entomology, Savannakhet \\ Province, Lao PDR; ${ }^{6}$ National Institute of Public Health, Ministry of Health, Lao PDR; ${ }^{7}$ School of Tropical Medicine and Global Health, Nagasaki \\ University, Nagasaki, Japan
}

\begin{abstract}
In the present study, we report on the occurrence of paramphistomes, Fischoederius cobboldi and Paramphistomum epiclitum, in Lao PDR with the basis of molecular data. Parasite materials were collected from bovines bred in Ban Lahanam area, Savannakhet Province, Lao PDR at Lahanam public market. Morphological observations indicated 2 different species of paramphistomes. The mitochondrial gene cox1 of the specimens was successfully amplified by PCR and DNA sequencing was carried out for diagnosis of 11 specimens. Pairwise alignment of cox 1 sequences were performed and confirmed $F$. cobboldi and $P$. epiclitum infecting bovines in Laos. Although there were many limiting points, as the small number of worm samples, and the restricted access of the animal host materials, we confirmed for the first time that 2 species of paramphistomes, F. cobboldi and P. epiclitum, are distributed in Lao PDR. More studies are needed to confirm the paramphistome species present in Savannakhet and its hosts to clear the natural history of these parasites of ruminants in the region and measure the impact of this parasite infection in the life and health of the local people.
\end{abstract}

Key words: Fischoederius cobboldi, Paramphistomum epiclitum, cattle, eco-health, amphistome, helminth, Laos

Paramphistomes, the rumen flukes, are parasites that infect ruminants, including cattle, goats, sheep, and water buffaloes. The disease caused by these parasites is a major cause of productivity and economic losses in different countries [1-3]. Life cycles of paramphistomes involve mammals as definitive hosts (DH) and snails as intermediate hosts (IH). Infection occurs when DH passively ingests metacercariae. After the immature development in the small intestine, the fluke migrates to the rumen where it reaches the adult stage. Symptoms of paramphistomiasis include acute gastroenteritis, with high morbidity and mortality mostly among young animals. The chronic disease is characterized by lower nutrition conversion and decreas-

\footnotetext{
- Received 21 January 2016, revised 3 June 2016, accepted 7 July 2016.

*Corresponding author (marcello@dokkyomed.ac.jp)

(C) 2016, Korean Society for Parasitology and Tropical Medicine

This is an Open Access article distributed under the terms of the Creative Commons Attribution Non-Commercial License (http://creativecommons.org/licenses/by-nc/4.0) which permits unrestricted non-commercial use, distribution, and reproduction in any medium, provided the original work is properly cited.
}

ed milk and meat production [4-6]. High prevalence of paramphistomosis occurs in tropical and subtropical regions with reports from Africa, Asia, Australia, Eastern Europe, and Russia caused by specific species of the parasites depending on the region, which include Paramphistomum cervi, Gastrothylax crumenifer, P. microbothrium, P. ichikawai, P. explanatum, P. epiclitum, Calicophoron calicophorum, Cotylophoron cotylophorum, Fischoederius elongates, and F. cobboldi [1,5-10].

In Thailand, a neighboring country with Lao PDR, paramphistomiasis can reach prevalences of $80 \%$, caused mainly by P. cervi $[2,11]$. However, there are no reports of paramphistomes occurring in Lao PDR. Then, aiming to fill this lack of information, molecular identification of F. cobboldi and P. epiclitum from bovines was performed. This is the first description of the occurrence of these important parasites of livestock in this southeast Asian country.

Parasite materials were collected from bovines bred in Ban Lahanam, a previously described area [12-14] located in Sa- 
vannakhet Province, Lao PDR at Lahanam public market. Twenty specimens were collected from 4 individual rumens; the parasites were stored in 70\% ethanol for later study. Morphological analysis of the specimens collected in this study was carried out at Department of Helminthology, Faculty of Tropical Medicine, Mahidol University (Thailand), the molecular studies were done in the School of Health Sciences, Faculty of Medicine, Niigata University (Japan), Department of Tropical Medicine and Parasitology, Dokkyo Medical University (Japan) and Animal Laboratory, School of Medicine at Universidade Federal do Tocantins (Brazil).

Genomic DNA was extracted from single adult worms in a total of 11 specimens (P1 to P11) using a Wizard ${ }^{\circledR}$ Genomic DNA Purification Kit (Promega, Madison, Wisconsin, USA) and used as templates. Identification of each species collected was carried out based on nucleotide sequence of cox 1 amplified by PCR. A set of PCR primers were used for amplification with the following sequences; 5'-TGGTTTTTTGTGCATCCTGAGGTTTA-3' (COI forward) and 5'-AGAAAGAACGTAATGAAAATGAGCAAC-3' (COI reverse) [15]. PCR was performed with GoTaq ${ }^{\circledR}$ Master Mix (Promega). The PCR products were sequenced by ABI3730XL sequencer (Applied Biosystems, Foster City, California, USA) at Macrogen Inc. (Seoul, Korea) and at Dokkyo Medical University (Japan). The obtained sequences were aligned and compared with the same gene sequences from GenBank database using BioEdit version 7.1.3 [16]. The phylogenetic tree was reconstructed by using the neighbor-joining method evaluated by a bootstrap test based on 1,000 resamplings using MEGA version 6.0 [17].

This is the first study reporting the occurrence of F. cobboldi and P. epiclitum in Laos, with molecular confirmation by sequencing of mitochondrial cox1 gene. Although paramphistomes mixed infections occur in endemic areas [18], the concomitant parasitism of 2 these species is newly reported in the region and may frequently be occurring.

Morphological analysis of the specimens collected in this study revealed that they are Paramphistomoidea by comparison with keys for trematoda [19], with the following characteristics: Two types were observed, one with the total length of 7 $\mathrm{mm}$ and the other $5 \mathrm{~mm}$ length, both presented a conical shape, thick, and muscular; oral sucker terminal, ventral sucker large, located at posterior end of the body (Fig. 1). Unfortunately, accurate measurements were not possible due to the collecting conditions and alcohol fixation, and the worms were difficult in morphological identification. On other hand, DNA was

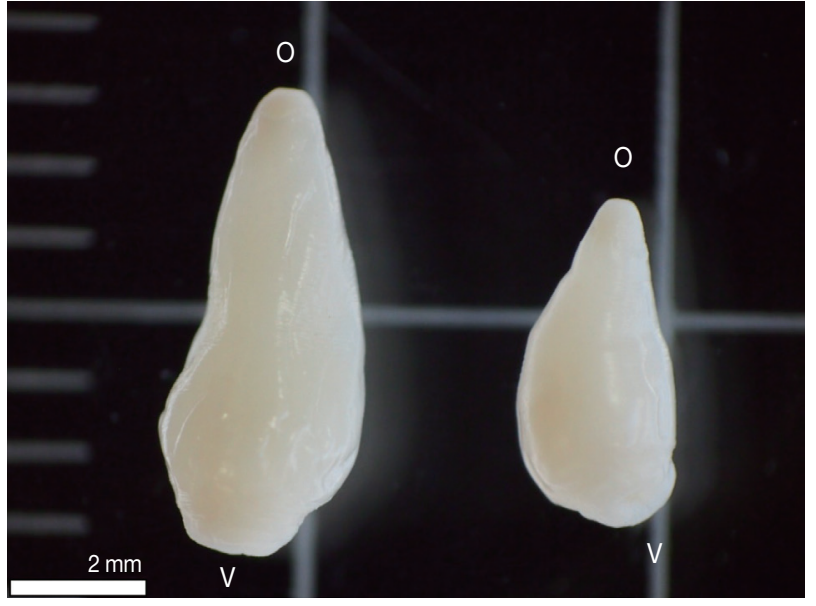

Fig. 1. Two types of amphistomes collected from bovine rumen in Lahanam, Lao PDR. Paramphistomum epiclitum (left) presented total length of $7 \mathrm{~mm}$ and Fischoederius cobboldi (right) $5 \mathrm{~mm}$ length, both presented a conical shape, thick, and muscular; oral sucker terminal (o); ventral sucker large (v) located at posterior end of the body.

successfully extracted, and cox 1 of 11 specimens were amplified producing amplicons of 446 base pairs, submitted for DNA sequencing (GenBank databases accession nos. from LC113915 to LC113925). Pairwise alignment of cox1 sequences were performed and elucidated the morphological types found (Fig. 2). With these morphological and genetic characteristics, this study confirmed the presence of 2 species, F. cobboldi and P. epiclitum in Lahanam, Lao PDR. These findings differ from other studies in Thailand where predominantly $P$. cervi was identified $[2,11]$. In our study, cox1 sequencing revealed higher identity with $P$. epiclitum and F. cobboldi, both newly identified in the region in this study. The analyses conducted using the maximum composite likelihood model [20] presented a homology of $87 \%$ between F. cobboldi and P. epiclitum found in this study. However, more molecular studies on the taxonomy of paramphistomes are necessary, once the small amount of information in the database jeopardizes the accuracy of the molecular identification. A review in the classification of paramphistomes using molecular data may help to reduce orders and regrouping taxa as considered by Sanabria and Romero [21].

There is lack of information on the pathogenesis of the 2 species found in this study and also no studies using experimental infections. However, in studies mainly with P. cervi infections, it is evident that there is importance of rumen flukes on livestock in endemic areas [22-25]. The migration of immature paramphistomes through the intestinal tract can cause acute parasitic gastroenteritis with high morbidity and mortal- 


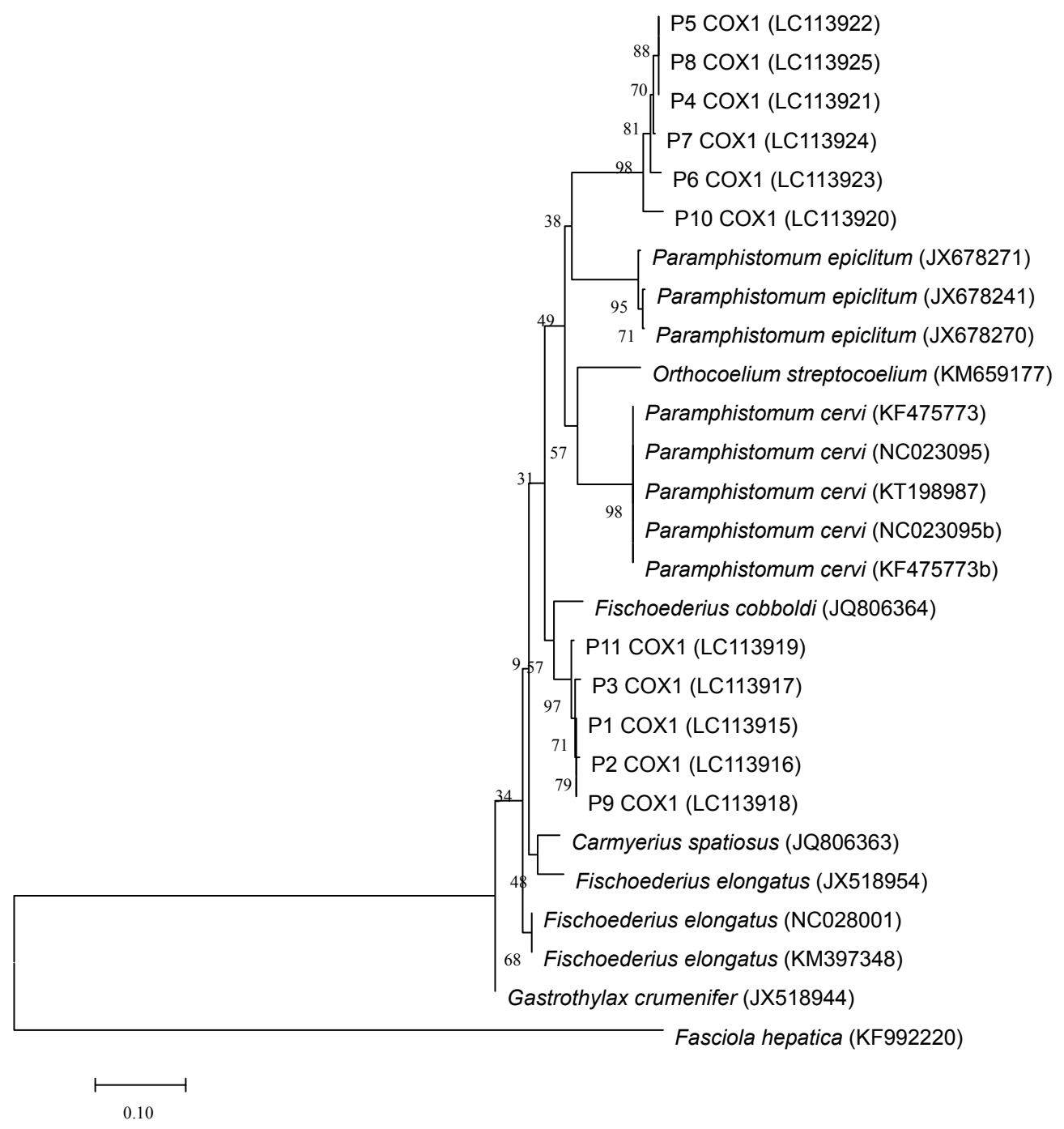

Fig. 2. Phylogenetic tree of the paramphistomes of ruminants constructed based on the partial cox 1 using the neighbor-joining method. Percentage of replicate trees in which the associated taxa clustered together in the bootstrap test $(1,000$ replicates) are shown next to the branches. The 11 specimens analyzed in this study are indicated as P1COX1 to P11COX1 and the reference sequences are shown by species and their respective GenBank accession numbers. The cox 1 sequence of Fasciola hepatica was used as an out-group.

ity, particularly in young animals $[1,6,22-25]$. The damage in the intestinal tract caused by parasites reduce nutrient availability to the host through both reductions in voluntary food intake and/or reductions in the efficiency of absorbed nutrients [26] causing a direct impact on the production of meat and milk. In our study, according to the meat sellers at the local markets, these parasites are frequently seen in the meat sold in Savannakhet city, and it may be causing important of economic losses, as previously described with other paramphistome infections $[6,25]$. Another important point on paramphistomiasis is that the disease is often not diagnosed. Usually, the diagnosis of paramphistomosis is based on the history and clinical signs of the disease with confirmation done by detection of paramphistome eggs in fecal examination. However, this method often results in misdiagnosis $[1,25,27,28]$. Then, sequencing cox 1 can be useful to make an accurate diagnosis once it can be done with different sources of parasite DNA, including environmental DNA as eggs in fecal samples [14,25, 29,30].

In this study, the occurrence F. cobboldi and P. epiclitum was determined for the first time in Lao PDR and its mitochondrial gene cox 1 was successfully sequenced, adding basic information on the paramphistomes of southeast Asia. Though, more studies are needed to determine the rumen fluke species pres- 
ent in Savannakhet and its hosts to clear the natural history of these parasites of ruminants in the region and measure the impact of paramphistomosis in the life of the local people.

\section{ACKNOWLEDGMENTS}

We would like to thank the people of Lahanam Village for their kind cooperation. In addition, we would like to thank Mr. Nirandon Homsuwan from the Department of Helminthology, Faculty of Tropical Medicine, Mahidol University for his generous assistance in the field. This research was supported by the Research Institute for Humanity and Nature project 'Environmental Changes and Infectious Diseases in Tropical Asia', for Kazuhiko Moji.

\section{CONFLICT OF INTEREST}

We have no conflict of interest related to this work.

\section{REFERENCES}

1. Horak IG. Paramphistomiasis of domestic ruminants. Adv Parasitol 1971; 9: 33-72.

2. Prasitirat $P$, Chompoochan $T$, Nithiuthai $S$, Wongkasemjit $S$, Punmamoamg T, Pongrut $\mathrm{P}$, Chinone S, Itagaki H. Prevalence of amphistomes of cattle in Thailand. Parasitol Hung 1997; 29/30: 27-32.

3. Nascimento CG, Nascimento AA, Mapeli EB, Tebaldi JH, Duarte JMB, Hoppe EGL. Natural infection by Paramphistomoidea Stiles and Goldberger, 1910 trematodes in wild marsh deer (Blastocerus dichotomus Illiger, 1815) from Sérgio Mottas's hydroelectric power station flooding area. Rev Bras Parasitol Vet 2006; 15: 133-137.

4. Prasitirat P, Nithiuthai S, Ruengsuk K, Kitwan P, Bunmatid C, Roopan S, Itagaki H. Efficacy of bithionol sulfoxide, niclosamide and fenbendazole against natural rumen fluke infection in cattle. Helminthologia 1997; 34: 155-157.

5. Gupta PP, Singh B, Dutt SC. A note on amphistomiasis in an adult buffalo. Indian Vet J 1978; 55: 491-492.

6. Hanna REB, Williamson DS, Mattison RG, Nizami WA. Seasonal reproduction in Paramphistomum epiclitum and Gastrothylax crumenifer, rumen paramphistomes of the Indian water buffalo and comparison with the biliary paramphistome Gigantocotyle explanatum. Int J Parasitol 1988; 18: 513-521.

7. Nikitin VF. The course of acute enzootic amphistomiasis in calves in the lower Volga region. Helminthol Abst Ser A 1979; 48: 46.

8. Katiyar RD, Grag RK. Comparative efficacy of various chemotherapeutic agents in amphistomiasis. Indian Vet J 1965; 42: 761-768.

9. Brotowidjoyo MD, Copeman DB. Abattoir survey of bovine paramphistomiasis in North Queensland. Austral Vet J 1979; 55:
402.

10. Wang CR, Qiu JH, Zhu XQ, Han XH, Ni HB, Zhao JP, Zhou QM, Zhang HW, Lun ZR. Survey of helminths in adult sheep in Heilongiiang Province, People's Republic of China. Vet Parasitol 2006; 140: 378-382.

11. Chethanon U, Ausavamatha P, Piriyayon S. Parasitological survey of cattle in the south of Thailand. Proceedings of the 4th Annual Livestock Conference, 3-5 July 1985, Department of Livestock Development 1985: 281-290.

12. Sato M, Thaenkham U, Dekumyoy P, Waikagul J. Discrimination of O. viverrini, C. sinensis, $H$. pumilio and H. taichui using nuclear DNA-based PCR targeting ribosomal DNA ITS regions. Acta Trop 2009; 109: 81-83.

13. Sato M, Pongvongsa T, Sanguankiat S, Yoonuan T, Dekumyoy $P$, Kalambaheti T, Keomoungkhoun M, Phimmayoi I, Boupha B, Moji K, Waikagul J. Copro-DNA diagnosis of Opisthorchis viverrini and Haplorchis taichui infection in an endemic area of Lao PDR. Southeast Asian J Trop Med Pub Health 2010; 41: 28-35.

14. Sato M, Pongvongsa T, Sanguankiat S, Yoonuan T, Kobayashi J, Boupha B, Nishimoto F, Moji K, Sato MO, Waikagul J. Patterns of trematode infections of Opisthorchis viverrini (Opisthorchiidae) and Haplorchis taichui (Heterophyidae) in human populations from two villages in Savannakhet Province, Lao PDR. J Helminthol 2015; 89: 439-45.

15. Bessho Y, Ohama T, Osawa S. Planarian mitochondria. 1. Heterogeneity of cytochrome $c$ oxidase subunit 1 gene sequences in the freshwater planarian, Dugesia japonica. J Mol Evol 1992; 34: 324-330.

16. Hall TA. BioEdit: a user-friendly biological sequence alignment editor and analysis program for Windows 95/98/NT. Nucl Acids Symp Ser 1999; 41: 95-98.

17. Tamura K, Stecher G, Peterson D, Filipski A, Kumar S. MEGA6: Molecular Evolutionary Genetics Analysis, version 6.0. Mol Biol Evol 2013; 30: 2725-2729.

18. Uddin MZ, Farjana T, Begum N, Mondal MMH. Prevalence of amphistomes in black Bengal goats in Mymensingh district. Bangl J Vet Med 2006; 4: 103-106.

19. Jones A, Bray RA, Gibson DI. Keys to the Trematoda. Volume 2. Wallingford, UK, CABI Publishing and The Natural History Museum. 2005, pp 1-768.

20. Tamura K, Nei M, Kumar S. Prospects for inferring very large phylogenies by using the neighbor-joining method. Proc Natl Acad Sci USA 2004; 101: 11030-11035.

21. Sanabria REF, Romero JR. Review and update of paramphistomosis. Helminthologia 2008; 45: 64-68.

22. Boray JC. Studies on intestinal amphistomosis in cattle. Austral Vet J 1959; 35: 282-287.

23. Chinone S. Paramphistomes of domestic animals. J Japan Vet Med Assoc 1979; 32: 661-670.

24. Noble ER, Noble GA. The Biology of Animal Parasites. Philadelphia, USA. Lea \& Febiger. 1982, pp 174-175.

25. Tandon V, Roy B, Shylla JA, Ghatani S. Amphistomes. Adv Exp Med Biol. 2014; 766: 365-392. 
26. Coop RL, Kyriazakis I. Nutrition-parasite interaction. Vet Parasitol 1999; 84: 187-204.

27. Bida SA, Schillhorn van Veen T. Enteric paramphistomiasis in Yankasa sheep. Trop Anim Health Prod 1977; 9: 21-23.

28. Kelly TD, Henderson AWK. Calicophoron calicophorum (Trematoda: Paramphistomatide) and paramphistomiasis in domestic cattle in the east Kimberley district of Western Australia. Trop Anim Health Prod 1973; 5: 192-195.
29. Lotfy WM, Brant SV, Ashmawy KI, Devkota R, Mkoji GM, Loker ES. A molecular approach for identification of paramphistomes from Africa and Asia. Vet Parasitol 2010; 174: 234-240.

30. Sato MO, Sato M, Chaisiri K, Maipanich W, Yoonuan T, Sanguankiat S, Pongvongsa T, Boupha B, Moji K, Waikagul J. Nematode infection among ruminants in monsoon climate (Ban-Lahanam, Lao PDR) and its role as food-borne zoonosis. Rev Bras Parasitol Vet 2014; 23: 80-84. 